\title{
Perkinsus olseni detected in Vietnamese aquacultured reef clams Tridacna crocea imported to the USA, following a mortality event
}

\author{
Barbara J. Sheppard*, Ayanna Carla Phillips \\ Department of Infectious Diseases and Pathology, Box 110880, College of Veterinary Medicine, University of Florida, \\ 2015 SW 16th Avenue, Gainesville, Florida 32611, USA
}

\begin{abstract}
Morbidity and mortality were observed in a group of 30 reef clams Tridacna crocea that were imported to Florida, USA, from a Vietnamese culture facility and held in research facility aquaria. Clinical signs included an incompletely extended mantle, slow mantle responses to stimuli, and sloughing of byssal tissue beginning 2 to $5 \mathrm{~d}$ prior to death. Necropsy findings included emaciation, visceral mass edema, and rare multifocal $1 \mathrm{~mm}$ off-white to light-tan gill nodules. Histopathology revealed marked inflammation and necrosis within the visceral mass and gills, with interstitial edema and atrophy of glandular, gonadal, and muscular tissues. Inflamed tissues contained large numbers of 10 to $15 \mu \mathrm{m}$ extracellular round organisms consistent with Perkinsus sp. trophozoites. The organisms often formed clusters of 1 to 4 cells and were surrounded by a 1 to $3 \mu \mathrm{m}$ rim of eosinophilic material variably forming a radiating corona pattern and by 3 to 4 host hemocytes with dense round nuclei. Polymerase chain reaction assays indicated the presence of Perkinsus sp. DNA in these animals, and species-specific assays indicated the presence of $P$. olseni, and possibly other Perkinsus spp., but not P. marinus. Identification of Perkinsus spp. other than P. marinus in T. crocea imported from Vietnam confirms that importation of untested and unquarantined ornamental reef clams has possibly allowed incursion of $P$. olseni into the USA.
\end{abstract}

KEY WORDS: Perkinsus olseni $\cdot$ Tridacna crocea $\cdot$ Bivalve $\cdot$ Inflammation $\cdot$ Vietnam Resale or republication not permitted without written consent of the publisher

\section{INTRODUCTION}

Perkinsus spp. are important destructive pathogens of mollusks (Villalba et al. 2004). There are many known species, which cannot be distinguished either morphologically or by culture in Ray's fluid thioglycollate medium (RFTM) (Casas et al. 2002, Dungan et al. 2002, Burreson et al. 2005). Microscopically, the organisms in tissue are characterized by 5 to $15 \mu \mathrm{m}$ spherical cells, with a prominent vacuole, an eccentric nucleus, and stimulate a host immune response characterized by hemocyte infiltration and a peripheral zone of eosinophilic material derived from hemocyte degranulation (Sagrista et al. 1995, Montes et al. 1997, Villalba et al. 2004). Molecular diagnostic tech- niques are necessary to distinguish the many species and strains of Perkinsus, and development of these assays is an ongoing process (de la Herrán et al. 2000, Penna et al. 2001, Reece et al. 2001, Robledo et al. 2002, Brown et al. 2004, Russell et al. 2004, Burreson et al. 2005, Park et al. 2005). Molecular characterization involves comparison of nucleotide sequences of the internal transcribed spacer (ITS) region, large subunit (LSU), and nontranscribed spacer (NTS) region of the ribosomal RNA gene, and actin genes (Dungan \& Reece 2006).

Perkinsus olseni has a broad geographic range that includes the Pacific Ocean around Japan, eastern Asia, New Zealand, and Australia, with expansion, believed to be anthropogenic, into the European Atlantic and 
Mediterranean areas (Dungan \& Reece 2006). The current extensive geographic range of $P$. olseni is the apparent result of inadvertent transplantation of the organism to new areas upon movement of aquaculture stocks (Le Borgne 1996) and most likely also mechanical vectors such as ballast from ships. P. olseni infections have been identified in many types of mollusks from different regions, e.g. carpet shell clams Ruditapes decussatus in Spain (Ordas et al. 2001), Venus clams Protothaca jedoensis in Korea (Park et al. 2006), and New Zealand cockles Austrovenus stutchburyi from northern New Zealand coastal waters (Dungan et al. 2007). P. olseni is also found in dual infections with other Perkinsus spp. such as the newly identified $P$. honshuensis in Japanese Manila clams Venerupis philippinarum from Gokasho Bay, Japan (Dungan \& Reece 2006).

Perkinsus olseni ( $=P$. atlanticus) has been found in tridacnid clams and many other types of mollusks at multiple sites on the Great Barrier Reef of Australia. Following the identification of Perkinsus sp. in Tridacna maxima (Perkins 1985), a survey of the P. olseni infection status of multiple reef mollusks revealed moderate to heavy infection in T. gigas, T. maxima, and $T$. crocea, in addition to detection of the organism in mollusks of the families Chlamidae, Arcidae, and Spondylidae on multiple islands off the coast of Queensland (Goggin \& Lester 1987). The intensity of $P$. olseni infections in $T$. crocea from Lizard Island was directly correlated with shell length, indicating that heavier infections were found in animals with larger shells (Goggin 1996). The economically important abalone industry of South Australia, including the blacklip abalone Haliotis rubra and greenlip abalone $H$. laevigata, was found to be negatively impacted by P. olseni, which caused large muscle abscesses (Lester \& Davis 1981). Cross-infection experiments with Australian P. olseni cultured from T. gigas, T. maxima, and $T$. crocea from the Orpheus, Heron, and Lizard Island reefs were used to successfully infect multiple types of mollusks, including Pinctada sugillata, Saccostrea commercialis, Pyrazus ebinenus, and Anadara trapezia (Goggin et al. 1989).

The western hemisphere has remained free of Perkinsus olseni, with the exception of the southwestern Atlantic coast of Uruguay, where $P$. olseni was identified in the commercially important venerid clam Pitar rostrata (Cremonte et al. 2005). Plans were underway in 2004 to import $P$. olseni-infected Manila clams Venerupis philippinarum from Korea to Mexican waters for distribution as stock to the North American west coast aquaculture industries (Elston et al. 2004). This movement of stock was blocked, thereby preventing contamination of the Central and North American Perkinsus-free regions.
According to the Convention on International Trade in Endangered Species (CITES) trade statistics (www. cites.org/eng/com/AC/22/E22-10-2-A8c.pdf; CITES Trade Database, UNEP World Conservation Monitoring Centre, Cambridge, UK), Tridacna crocea exports were recorded for 24 countries and territories in the Indo-Pacific between 1994 and 2003. The greatest numbers of exported T. crocea originate in Vietnam for which, like the other exporting countries and territories, the Perkinsus olseni infection rate and intensity is unknown. Information is needed about the possible $P$. olseni infection status of ornamental tridacnid clams that are currently imported into the USA without testing or quarantine. In the current study, identification of Perkinsus spp. other than $P$. marinus in $T$. crocea imported from Vietnam confirms that importation of untested and unquarantined ornamental reef clams has potentially allowed incursion of $P$. olseni into the USA. The frequency and intensity of infections in imported ornamental Tridacna and the extent to which nondomestic Perkinsus spp. have been distributed within the USA is unknown.

\section{MATERIALS AND METHODS}

Procurement of animals. In mid-September 2005, 30 adult (8.5 to $11 \mathrm{~cm}$ length) boring or crocus clams Tridacna crocea were obtained from the warehouse facility of a Florida, USA, importer in their individual unopened shipping bags immediately upon arrival from a culture facility in Vietnam. These animals were a subset of a larger shipment of Tridacna clams received at the warehouse. They were transported to research facility aquaria in the Department of Infectious Diseases and Pathology at the University of Florida, Gainesville. The clams were intended for use in a pilot study examining the potential relationship between gonadal development and light exposure regimens following a 3 mo acclimation and quarantine period. However, the study was not performed due to ongoing morbidity and mortality during that $3 \mathrm{mo}$ period.

Laboratory conditions. Within the research facility, 10 clams were placed in each of 3 plastic containers (30 quart [ 28.4 l] volume) containing an aragonite substrate and 32 to 34 psu artificial seawater (deionized water and Oceanic Natural Sea Salt Mix, Oceanic Systems) at $\mathrm{pH}$ 8.2. Water was recirculated through each tank by gravity flow to wet-dry filters and returned by a powerhead (AquaClear 50, 270 gallon $\left.\mathrm{h}^{-1}\left[\sim 1022 \mathrm{l} \mathrm{h}^{-1}\right]\right)$ and T-tube. The wet-dry filters consisted of 10 gallon ( 37.85 l) plastic containers with 1 gallon ( $\sim 3.785$ l) of bio-balls. The tanks were kept at ambient room and water temperatures of $78^{\circ} \mathrm{F}\left(26^{\circ} \mathrm{C}\right)$, 
with no ancillary heating in a quiet area with a $400 \mathrm{~W}$ mogul base metal halide bulb within a parabolic reflector on a 13:11 h light:dark cycle and a weekly $50 \%$ water change. The system was allowed to establish a biofilter for $4 \mathrm{wk}$ prior to the addition of clams, and the exposure time to light was gradually increased in order to facilitate acclimation. A commercial algal mixture (Phytofeast, Reed Mariculture) was provided daily for the first $3 \mathrm{wk}$.

Health monitoring. During the 3 mo acclimation and quarantine period, the animals were observed for signs of morbidity and mortality. Clinical signs of morbidity were subjective and included mantle changes such as slow retraction in response to stimuli and less than complete extension during 'sunning', and sloughing of large gelatinous pieces of byssal tissue. Moderate to marked morbidity and mortality were indicated by minimal retention or total loss, respectively, of mantle and shell movements in response to stimuli.

Necropsy, tissue collection, and histopathology. Twenty-seven animals were removed from the aquaria when they demonstrated signs of moderate to marked morbidity or death. On December 22, 2006 three Tridacna crocea with milder clinical signs of morbidity were necropsied in addition to 3 markedly morbid or dead animals to facilitate comparison of their tissues. Tissue samples from the final 9 animals necropsied between December 22, 2006 and January 9, 2006 were frozen at $-80^{\circ} \mathrm{C}$ for DNA analysis. Water samples from the aquaria on the final day of necropsy, January 9, 2006 , were also frozen at $-80^{\circ} \mathrm{C}$. Gill, mantle, and main body mass tissues from all $30 \mathrm{~T}$. crocea were placed in $10 \%$ neutral buffered formalin. Formalin-fixed tissues were trimmed, routinely processed, paraffin-embedded, and examined as $5 \mu \mathrm{m}$ hematoxylin and eosinstained sections on standard glass slides by light microscopy. Light microscopic evaluation of fresh samples of the greenish brown biofilm of each tank was also performed for comparison to organisms found in the tissues that might be due to normal filter-feeding activity.

Ray's fluid thioglycollate culture for Perkinsus spp. Frozen Tridacna crocea tissues and fresh regional Crassostrea virginica infected with Perkinsus marinus (from a local grocery store) used as a positive control were cultured for the presence of Perkinsus spp. hypnospores. A positive control for $P$. olseni was not available. Tissues were incubated in fluid thioglycollate medium (FTM) (Difco) containing $500 \mathrm{U}$ penicillin and $500 \mathrm{mg}$ dihydrostreptomycin $\mathrm{ml}^{-3}$ of medium for $7 \mathrm{~d}$ in the dark at room temperature. A sample of each gill was stained with Lugol's iodine and examined by light microscopy for the presence of hypnospores.

DNA extraction. DNA was extracted from frozen tissue of 5 Tridacna crocea, fresh Crassostrea virginica tissues naturally infected with Perkinsus marinus, and FTM cultures of $C$. virginica containing abundant $P$. marinus hypnospores using the Promega Wizard Genomic DNA Purification Kit according to the manufacturer's protocol. DNA, suspended in rehydration solution provided in the DNA purification kit, was stored at $-20^{\circ} \mathrm{C}$.

Polymerase chain reaction (PCR). DNA from frozen Tridacna crocea tissue (4 animals), fresh Crassostrea virginica tissue, and FTM cultures of $C$. virginica containing abundant hypnospores was subjected to PCR assays using published primers specific for Perkinsus marinus (forward: DERMO A1 5'-CACTTGTATTGTG AAGCACCC-3'; and reverse: DERMO D 5'-GTGACA TCTCCAAATGACC-3'), which were expected to yield a 304 base pair (bp) product (Penna et al. 2001). PCR assays with the same tissue sets were also performed using published primers for amplification of partial inter-genic spacer (IGS) sequences (319 bp) of $P$. marinus, $P$. olseni and $P$. chesapeakii $(=P$. andrewsi) (forward: PER1 5'-TAGTACCCGCTCATY GTGG-3' and reverse: PER2 5'-TGCAATGCTTGC GAGCT-3') (Robledo et al. 2002). PCR assays were performed with those tissue sets supplemented with an additional T. crocea using published primers for the NTS region $(554 \mathrm{bp})$ of $P$. olseni (= P. atlanticus) (forward: $P$. olseni A 5'-ACCAGTCACAGGGCGTA AT-3'; and reverse: P. olseni B 5'-GTAGCGTGCTCT GATGATCACT-3'). Crassostrea virginica tissues and cultured hypnospores were used as positive PCR controls for P. marinus, the pathogenic Perkinsus sp. commonly found in $C$. virginica. A positive control for $P$. olseni was not available. In negative controls, template DNA was substituted by nuclease-free water. PCR reactions were performed using approximately $50 \mathrm{ng}$ DNA template, $10 \mu \mathrm{l}$ of $10 \times$ buffer, $4 \mu \mathrm{l}$ of $50 \mathrm{mM} \mathrm{MgCl}_{2}, 2 \mu \mathrm{l}$ of $10 \mu \mathrm{M}$ dNTPs, $0.5 \mu \mathrm{l}$ Taq polymerase $\left(5 \mathrm{U} \mathrm{\mu l}^{-1}\right), 40 \mathrm{pmol}$ of primers and nucleasefree water, to a total reaction volume of $100 \mu \mathrm{l}$. All PCR reactions were performed in the Eppendorf Mastercycler gradient thermal cycler (Perkin-Elmer). Reactions containing the PER1 and PER2 primers were carried out using an initial denaturation step at $94^{\circ} \mathrm{C}$ for $4 \mathrm{~min}$, followed by 35 cycles of $91^{\circ} \mathrm{C}$ for $1 \mathrm{~min}$, $60^{\circ} \mathrm{C}$ for $1 \mathrm{~min}$, then $72^{\circ} \mathrm{C}$ for $1 \mathrm{~min}$, followed by final extension at $72^{\circ} \mathrm{C}$ for $7 \mathrm{~min}$ (Robledo et al. 2002). Reactions containing the DERMO A1 and DERMO D primers were carried out using an initial denaturation step at $94^{\circ} \mathrm{C}$ for $12 \mathrm{~min}$, followed by 35 cycles of $94^{\circ} \mathrm{C}$ for $45 \mathrm{~s}, 50^{\circ} \mathrm{C}$ for $1 \mathrm{~min}$, then $72^{\circ} \mathrm{C}$ for $2.5 \mathrm{~min}$, followed by final extension at $72^{\circ} \mathrm{C}$ for $7 \mathrm{~min}$ (Penna et al. 2001). Reactions containing the P. olseni A and B primers were carried out using an initial denaturation step at $94^{\circ} \mathrm{C}$ for $4 \mathrm{~min}$, followed by 35 cycles of $92^{\circ} \mathrm{C}$ for $1 \mathrm{~min}, 60^{\circ} \mathrm{C}$ for $1 \mathrm{~min}$, then $72^{\circ} \mathrm{C}$ for $1 \mathrm{~min}$, fol- 
lowed by final extension at $72^{\circ} \mathrm{C}$ for $7 \mathrm{~min}$. Gel electrophoresis was used for detection of amplified PCR products. A volume of $4 \mu \mathrm{l}$ of PCR product was loaded into each well and was subjected to electrophoresis at $100 \mathrm{~V}$ in a horizontal, ethidium-bromide-stained $\left(0.1 \mathrm{~g} \mathrm{l}^{-3}\right), 2 \%$ agarose gel (GIBCO BRL UltraPureLife Technologies) with $1 \times$ Tris acetate/sodium EDTA buffer. A 100 bp DNA ladder was included on each gel as a size standard. Gels were exposed to ultraviolet light to visualize the amplified products and photographed (GelDoc 2000, BioRad).

\section{RESULTS}

\section{Clinical observations}

Following an initial 6 wk of apparent health in the research facility aquaria, individual clams Tridacna crocea began to die at a rate of 1 to 3 per week, with the death of all clams by January 9, 2006. By December 20,2005, the temperature and $\mathrm{pH}$ had gradually dropped to $20^{\circ} \mathrm{C}$ and 7.8 , respectively, which was corrected by addition of heaters and sodium bicarbonate to reestablish $\mathrm{pH} 8.2$ and raise the temperature to $26^{\circ} \mathrm{C}$. Following correction of these potential stressors, there was a $10 \mathrm{~d}$ period without morbidity or mortality from December 27, 2005 to January 5, 2006, after which the remaining animals were clinically sick or dead by January 9, 2006.

\section{Gross necropsy findings}

The overall body size appeared small for the shell, which was consistent with mild to severe atrophy (Fig. 1). There was generalized mild to marked edema of the body mass, and the visceral mass area of the main body mass was expanded, soft, and watery. There were occasional 0.5 to $1.5 \mathrm{~mm}$ fine off-white to tan nodules on the gills, mantle, and body mass tissues. Many clams were in a state of advanced autolysis. Clinically less affected clams necropsied on December 22, 2005 for comparison were characterized by less severe atrophy and edema.

\section{Histopathology}

The visceral gland and associated gonadal and connective stroma were moderately to markedly edematous and markedly infiltrated by hemocytes (Fig. 2A). Glandular, gonadal, and muscular tissues were atrophied. Within the affected visceral gland, there were many 10 to $15 \mu \mathrm{m}$ extracellular round organisms (trophozoites or aplanospores), often forming clusters of 1 to 4 cells and having an eccentric vacuole or signet ring appearance. Organisms were frequently surrounded by a 1 to $3 \mu \mathrm{m}$ rim of eosinophilic material, variably forming a radiating corona pattern and with 3 or 4 round cells at the periphery having a round dense nucleus suggestive of host hemocytes (Fig. 2B). Some organisms formed aggregates or clusters embedded or surrounded by amorphous material (Fig. 2C). Distinct doublets were frequently identified (Fig. 2D). Similar organisms were often identified in association with mild inflammation within the gills and other tissues. Renal tissue was generally edematous, with fewer organisms and less inflammation, but was readily identified by its oval mineral foci.

Large numbers of the Perkinsus sp.-like organisms were detected in all animals, including the 3 clinically less affected Tridacna crocea that were necropsied on December 22, 2005 for comparison to 3 other moribund or dead animals necropsied on the same day. Samples of the algal biofilm of the tanks examined by light microscopy did not contain organisms with a morphology similar to those in the T. crocea tissues or FTM cultures.

\section{Culture and PCR}

FTM cultures of Crassostrea virginica contained abundant 10 to $15 \mu \mathrm{m}$ dense oval hypnospores consistent with Perkinsus marinus. C. virginica tissues and FTM cultures with hypnospores from $C$. virginica were positive by PCR with generic Perkinsus spp. primers and species-specific primers for $P$. marinus, but negative for species-specific primers for P. olseni (Fig. 3). Frozen Tridacna crocea tissue FTM assays were negative, while the PCR assays on frozen tissues from the same 4 animals necropsied on December 22, 2005 were

Fig. 1. Tridacna crocea. Gross photographs of emaciated carcass. Left: top view of small mantle; middle and right: lateral view of clam shell and carcass after removal, demonstrating reduced body mass. Shell length $=9.5 \mathrm{~cm}$

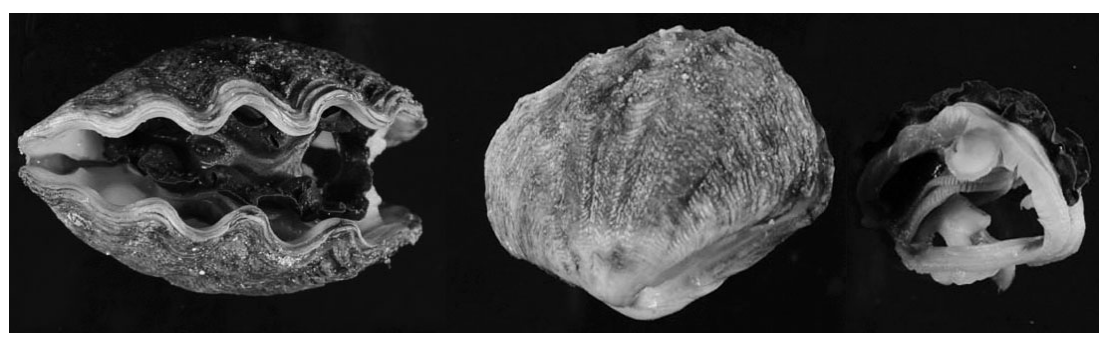




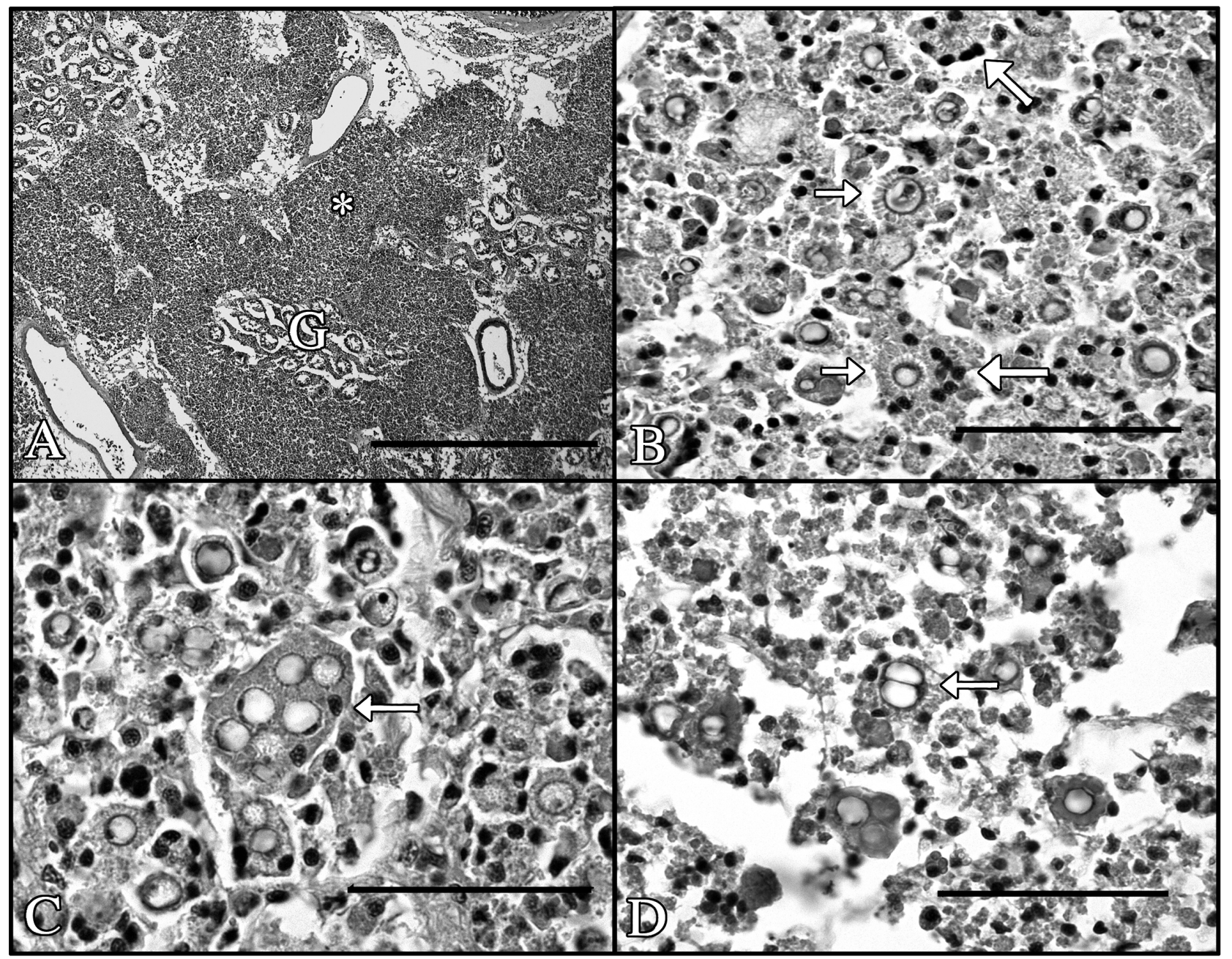

Fig. 2. Inflamed visceral gland of Tridacna crocea and associated Perkinsus sp. organisms. Hematoxylin and eosin stain. (A) Digestive gland (G) with dense inflammatory infiltrates and a large number of organisms (::5). Scale bar $=200 \mu \mathrm{m}$. (B) Inflamed digestive gland with abundant 10 to $25 \mu \mathrm{m}$ extracellular round organisms, some of which are surrounded by a 1 to $3 \mu \mathrm{m}$ rim of eosinophilic material variably forming a radiating corona pattern (arrows) and 3 to 4 round cells at the periphery with round dense nuclei consistent with a host inflammatory cell response (large arrows). (C) Some organisms formed large aggregates or clusters embedded or surrounded by amorphous eosinophilic material (arrow). (D) Doublets (arrow) consistent with organism division were common. Scale bars for $\mathrm{B}-\mathrm{D}=50 \mu \mathrm{m}$

positive for Perkinsus sp., indicating that freezing rendered the organism unable to be cultured in these conditions. Tissues from all 4 T. crocea were positive by PCR for generic Perkinsus spp. primers and negative for species-specific primers for $P$. marinus (Fig. 3). However, they had variable results with the $P$. olseni-specific primers, with no band for 2 animals (Lanes 3 and 4), a strong positive band for 1 animal (Lane 5), and weaker bands for 2 animals (Lanes 6 and 7).

\section{DISCUSSION}

The tissue reactions, organism morphology, and pattern of PCR results confirm the presence of large num- bers of Perkinsus sp. organisms other than P. marinus, and consistent with $P$. olseni in the inflamed tissues of sick and dead Tridacna crocea. The variable findings for the T. crocea tissues with Perkinsus genus primers and $P$. olseni-specific primers may reflect differences in the number of $P$. olseni organisms in different animals or tissues (subsampling error), or variability in the DNA target sequences for the different primer sets. However, variable results are also consistent with a dual infection of $P$. olseni and an unknown Perkinsus sp. as recently described for $P$. honshuensis in Japanese Manila clams Venerupis philippinarum from Gokasho Bay, Japan (Dungan \& Reece 2006). Additional investigations with clonal cultures of the Perkinsus sp. organism(s) will facilitate that determination. 


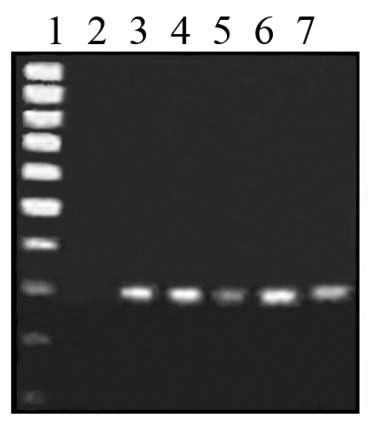

A

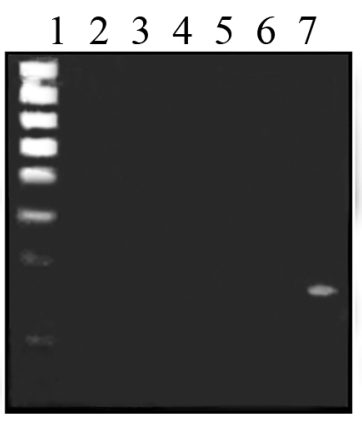

B

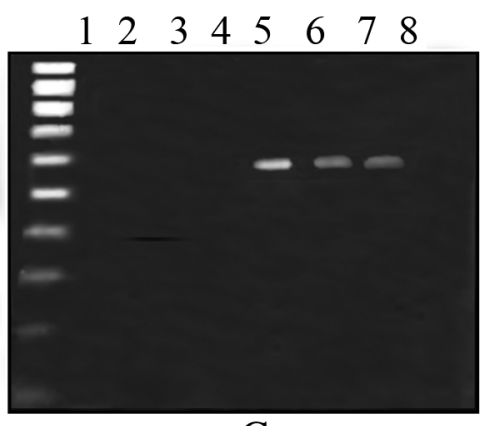

C

Fig. 3. Tridacna crocea and Crassostrea virginica. Results of PCR for Perkinsus sp. organisms. Lane identification for Panels (A) and (B) - 1: 100 bp DNA ladder; 2: negative control; 3 to 6: 4 T. crocea individuals; 7: C. virginica. Lane identification for Panel (C) - 1: 100 bp DNA ladder; 2: negative control; 3 to 7: 5 T. crocea individuals; 8: C. virginica. (A) PER1/2 primers genus-specific for $P$. marinus, $P$. chesapeaki (= P. andrewsi), and P. olseni (= P. atlanticus) yielded a positive reaction for all $T$. crocea samples (Lanes 3 to 6) and C. virginica (Lane 7). (B) DERMO A1/D primers species-specific for $P$. marinus yielded a positive reaction for C. virginica (Lane 7), but not for T. crocea samples. (C) P. olseni A/B primers species-specific for $P$. olseni (= P. atlanticus) yielded a positive reaction $554 \mathrm{bp}$ band for $3 \mathrm{~T}$. crocea samples (Lanes 5 to 7), but not for $2 \mathrm{~T}$. crocea samples (Lanes 3 and 4 ) or C. virginica (Lane 8)

Not surprisingly, attempts to culture Perkinsus sp. from frozen Tridacma crocea tissues were unsuccessful. The organism requires membrane stabilization in DMSO prior to freezing to remain viable for culture upon thawing (Dungan et al. 2002, Burreson et al. 2005).

The presence of the Perkinsus sp. organisms does not confirm that they are responsible for the morbidity and mortality observed in these animals, but infection intensity based on histology was consistent with that of lethal Perkinsus sp. infections in other hosts (Villalba et al. 2004). It is unclear to what extent the temporary variation from optimal temperature and $\mathrm{pH}$ may have stressed the host animals. However, $P$. olseni-associated morbidity and mortality are enhanced by increased temperature (Ahn \& Kim 2001, Casas et al. 2002), thus making the mild drop in temperature in the aquaria an unlikely cause of observed enhanced infection.

The prevalence of infection or carrier status of imported Tridacna crocea with Perkinsus sp. is unknown as they are not subject to testing or quarantine in Florida or other states, such as California, which is the main port of entry for Tridacna clams entering the USA. However, ongoing surveillance for mollusk pathogens on both the west and east coasts of North America has never detected P. olseni, and these Tridacna spp. clams were never removed from their travel packaging until arrival at the research aquaria. Thus, it is very unlikely there was a local source of infection. $P$. olseni is known to infect $T$. crocea in the South Pacific (Goggin \& Lester 1987, Goggin 1996), so it is almost certain that the clams were infected when imported. This finding is cause for concern, because $P$. olseni is an Office International des Epizooties (OIE)- reportable pathogen that presently does not occur in North America, and this pathogen is clearly being imported with infected T. crocea. It has been shown that Perkinsus cells are released in the pseudofeces and feces of infected oysters (Bushek et al. 2002). In the absence of strict quarantine, this raises the possibility that consumption of dead Tridacna clams by predator species could result in fecal release of viable infective particles, in addition to trophozoite or zoospore release from dead or dying clam tissue. It is well documented that all life stages of Perkinsus sp. are infective (Villalba et al. 2004); thus, contaminated aquarium water could be a source of infection for other mollusks in aquaria, or for native natural hosts upon disposal of the water. Importation policies regarding importation of T. crocea into the USA, which currently do not require monitoring for potential pathogens either at export or import, or provide quarantine regulations, need to be reexamined.

Acknowledgements. The authors are grateful to Charles Courtney III, DVM, PhD for supporting this project.

\section{LITERATURE CITED}

Ahn KJ, Kim KH (2001) Effect of temperature and salinity on in vitro zoosporulation of Perkinsus sp. in Manila clams Ruditapes philippinarum. Dis Aquat Org 48:43-46

Brown GD, Hudson KL, Reece KS (2004) Multiple polymorphic sites at the ITS and ATAN loci in cultured isolates of Perkinsus marinus. J Eukaryot Microbiol 51:312-320

Burreson EM, Reece KS, Dungan CF (2005) Molecular, morphological, and experimental evidence support the synonymy of Perkinsus chesapeaki and Perkinsus andrewsi. J Eukaryot Microbiol 52:258-270

Bushek D, Ford SE, Chintala MM (2002) Comparison of in vitro-cultured and wild-type Perkinsus marinus. III. Fecal 
elimination and its role in transmission. Dis Aquat Org 51:217-225

Casas SM, Villalba A, Reece KS (2002) Study of perkinsosis in the carpet shell clam Tapes decussates in Galicia (NW Spain). I. Identification of the aetiological agent and in vitro modulation of zoosporulation by temperature and salinity. Dis Aquat Org 50:51-65

Cremonte F, Balseiro P, Figueras A (2005) Occurrence of Perkinsus olseni (Protozoa: Apicomplexa) and other parasites in the venerid commercial clam Pitar rostrata from Uruguay, southwestern Atlantic coast. Dis Aquat Org 64:85-90

de la Herrán R, Garrido-Ramos MA, Navas JI, Rejon CR, Rejon MR (2000) Molecular characterization of the ribosomal RNA gene region of Perkinsus atlanticus: its use in phylogenetic analysis and as a target for a molecular diagnosis. Parasitology 120:345-353

Dungan CF, Reece KS (2006) In vitro propagation of two Perkinsus spp. parasites from Japanese Manila clams Venerupis philippinarum and description of Perkinsus honshuensis n. sp. J Eukaryot Microbiol 53:316-326

Dungan CF, Hamilton RM, Hudson KL, McCollough CB, Reece KS (2002) Two epizootic diseases in Chesapeake Bay commercial clams, Mya arenaria and Tagelus plebeius. Dis Aquat Org 50:67-78

Dungan CF, Reece KS, Moss JA, Hamilton RM, Diggles BK (2007) Perkinsus olseni in vitro isolates from the New Zealand clam Austrovenus stutchburyi. J Eukaryot Microbiol 54:263-270

Elston RA, Dungan CF, Meyers TR, Reece KS (2004) Perkinsus sp. infection risk for Manila clams, Venerupis philippinarum (A. Adams and Reeve, 1850) on the Pacific coast of North and Central America. J Shellfish Res 23:101-105

Goggin CL (1996) Effect of Perkinsus olseni (Protozoa, Apicomplexa) on the weight of Tridacna crocea (Mollusca, Bivalvia) from Lizard Island, Great Barrier Reef. Aquaculture 141:25-30

Goggin CL, Lester RJG (1987) Occurrence of Perkinsus species (Protozoa, Apicomplexa) in bivalves from the Great Barrier Reef. Dis Aquat Org 3:113-117

Goggin CL, Sewel KB, Lester RJG (1989) Cross-infection experiments with Australian Perkinsus species. Dis Aquat Org 7:55-59

Le Borgne Y (1996) Échanges internationaux des mollusques bivalves et situation actuelle en France et en Europe. Rev Sci Tech 15:491-498

Lester RJG, Davis GHG (1981) A new Perkinsus species (Api-

Editorial responsibility: Eugene Burreson, Gloucester Point, Virginia, USA complexa, Perkinsea) from abalone Haliotis ruber. J Invertebr Pathol 37:181-187

Montes JF, Del Rio JA, Durfort M, Garcia-Valero J (1997) The protozoan parasite Perkinsus atlanticus elicits a unique defensive response in the clam Tapes semidecussatus. Parasitology 114:339-349

Ordas MC, Gomez-Leon J, Figueras A (2001) Histopathology of the infection by Perkinsus atlanticus in three clam species (Ruditapes decussates, $R$. philippinarum and $R$. pullastra) from Galicia (NW Spain). J Shellfish Res 20:1019-1024

> Park KI, Park JK, Lee J, Choi KS (2005) Use of molecular markers for species identification of Korean Perkinsus sp. isolated from Manila clams Ruditapes philippinarum. Dis Aquat Org 66:255-263

> Park KI, Ngo TTT, Choi SD, Cho M, Choi KS (2006) Occurrence of Perkinsus olseni in the Venus clam Protothaca jedoensis in Korean waters. J Invertebr Pathol 93:81-87

Penna MS, Khan M, French RA (2001) Development of a multiplex PCR for the detection of Haplosporidium nelsoni, Haplosporidium costale and Perkinsus marinus in the eastern oyster (Crassostrea virginica Gmelin, 1971). Mol Cell Probes 15:385-390

Perkins FO (1985) Range and host extensions for the molluscan bivalve pathogens, Perkinsus spp. In: Abstracts, VII International Congress of Protozoology, 1985, Nairobi, p 81

Reece KS, Bushek D, Hudson KL, Graves JE (2001) Geographic distribution of Perkinsus marinus genetic strains along the Atlantic and Gulf coasts of the USA. Mar Biol 139:1047-1055

Robledo JAF, Nunes PA, Cancela ML, Vasta GR (2002) Development of an in vitro clonal culture and characterization of the rRNA gene cluster of Perkinsus atlanticus, a protistan parasite of the clam Tapes decussates. J Eukaryot Microbiol 49:414-422

- Russell S, Frasca S Jr, Sunila I, French RA (2004) Application of a multiplex PCR for the detection of protozoan pathogens of the eastern oyster Crassostrea virginica in field samples. Dis Aquat Org 59:85-91

Sagrista E, Durfort M, Azevedo C (1995) Perkinsus sp. (Phylum Apicomplexa) in Mediterranean clam Ruditapes semidecussatus: ultrastructural observations of the cellular response of the host. Aquaculture 132:153-160

Villalba A, Reece KS, Camino Ordas M, Casa SM, Figueras A (2004) Perkinsosis in mollusks: a review. Aquat Living Resour 17:411-432

Submitted: August 8, 2007; Accepted: December 10, 2007 Proofs received from author(s): April 23, 2008 